\title{
The Black Sea and Blue Energy: Challenges, Opportunities and the Role of the European Union
}

\author{
Montserrat Abad Castelos
}

\section{Introduction}

The Black Sea enjoys enormous importance from a number of standpoints: if we consider all the economic, political, social and environmental factors that come together, its strategic nature for the world as a whole, not just Europe, is immediately apparent. In this regard, mention is often made of it serving as a bridge between Europe and Asia since it connects Europe with the Caspian Sea area, Central Asia, the Middle East and, going further, with South-East Asia and China. ${ }^{1}$ Its strategic nature is also due to its connection with certain wide-ranging threats of

This chapter has been written within the framework of the following research projects: "NETwork of experts on the Legal aspects of MARitime SAFEty and security (www.marsafenet.org), awarded by the European Union, COST Action IS1105 (Working Group IV, "Protection of Fragile and Semi-Enclosed Seas"); "Alianza Público-Privada en la Cooperación para el Desarrollo en el Sector Pesquero: Las Empresas Pesqueras Españolas en los Países en Desarrollo" [Public-Private Partnership in Cooperation for Development in the Fisheries Sector: The Spanish fishing companies in Developing Countries], awarded by the Spanish Ministry of Economy and Competitiveness (DER 2013-45995-R); "Actores económicos internacionales y derechos humanos. Especial relevancia para España” [International Economic Actors and Human Rights. Particular relevance for Spain], awarded by the Spanish Ministry of Economy and Competitiveness (DER2014-55484-P); and "Nuevos escenarios jurídicos marítimo-pesqueros y la protección de las gentes del mar" ["New legal scenarios in the maritime and fisheries sector and the protection of seafarers"] (Network of Excellence), awarded by the Spanish Ministry of Economy and Competitiveness (DER2015-70965-REDT).

${ }^{1}$ High-level Black Sea Stakeholder Conference (2014), Sustainable Development of the Blue Economy of the Black Sea, Background paper for the stakeholders conference, 30 January 2014, Bucharest, Romania, p. 4.

M. Abad Castelos $(\bowtie)$

Faculty of Social Science and Law, University Carlos III, Madrid, Spain

e-mail: montserrat.abad@uc3m.es 
a more global nature, such as human trafficking as a ramification of illegal migration, terrorism or drug trafficking.

Furthermore, when we talk of the Black Sea basin, we are in fact referring to an area that extends beyond the immediate environment of its waters: in addition to a respectable total of six riparian countries (Romania, Bulgaria, Turkey, Georgia, Russia and Ukraine), Greece, Armenia and Azerbaijan can also be considered to fall within its bounds.

There are obviously wide-ranging differences between the above-mentioned countries, according to a variety of indicators: economic development; governance, democracy and human rights protection; the pace at which reform is taking place in these aspects; access to energy resources (whilst one riparian country can be considered a veritable energy superpower, others are energy deficient and highly dependent on imports; some countries are energy producers, and others are simply countries through which energy passes); and their relationship with the EU. In the latter regard, some are EU Member States, and others are not: one is an EU candidate country (Turkey), others are European Neighbourhood Policy (ENP) partners and another (Russia) is a strategic partner for the EU. Amongst the ENP partner countries, three have shown willingness to achieve closer ties with the EU (Georgia, Moldova and Ukraine), whilst others evidence a certain degree of reticence and appear to favour partnerships with other interlocutors (Armenia, Azerbaijan). ${ }^{2}$ Additionally, there are a number of frozen conflicts within the area, such as those in the Republic of Moldova (Transnistria) and Georgia (Abkhazia and South Ossetia) or that between Armenia and Azerbaijan (the Nagorno-Karabakh enclave). To this we must add the serious conflict provoked by Russia's illegal annexation of Crimea in 2014, which has brought about a substantial modification in the strategic landscape not only of the Black Sea Basin itself but also of the outlying area, seen as an example of a broader systemic challenge to the European security architecture. ${ }^{3}$

In addition to the complex political situation described above, it must also be noted that the Black Sea ecosystem is suffering from substantial environmental degradation: as a virtually enclosed inland sea, it is particularly fragile from a physical standpoint, and its vulnerability has regrettably not been sufficiently compensated for by the introduction of appropriate policies to prevent its deterioration. The enormous pressure resulting from numerous human activities such as industrialisation, urbanisation, overfishing or transport (not only of hydrocarbons since the arrival of invasive species in ships' ballast water has also been proved to represent a serious environmental threat) has led to serious problems of pollution, loss of biodiversity, extinction of species and eutrophication, amongst others. ${ }^{4}$

\footnotetext{
${ }^{2}$ In relation to this policy, currently under review, see Review of the European Neighbourhood Policy, JOIN (2015) 50 final, 18.11.2015.

${ }^{3} \mathrm{Cf}$. The European Parliament, Report on the strategic military situation in the Black Sea Basin following the illegal annexation of Crimea by Russia, A8-0171/2015, DE 21-5-2015; p. 6.

${ }^{4}$ See, inter alia, Adams (1998), pp. 209-217; Postiglione (2007), pp. 489-500; Oral (2013), pp. 787-804, particularly pp. 789 ff.
} 
As is always the case in areas that suffer high volumes of traffic, the fragility of the environment is increased, particularly as far as hydrocarbons are concerned; in this regard, the Black Sea is a much-used corridor along which the latter are transported, mainly from the Caspian Sea, bringing with it the associated risk of accidental spillage. ${ }^{5}$ And as if this situation were not in itself cause for concern, the risks may be even greater in future, given the possibility of hydrocarbon exploitation in the Black Sea itself, with offshore oil and gas deposits pending exploration in Romania, Bulgaria and Turkey, which could add new sources of pollution to the existing ones. ${ }^{6}$ If this scenario were to occur, the Black Sea could possibly never recover from the consequences of a spill such as that which occurred in the Gulf of Mexico in 2010.

\section{Sustainable Development and Blue Energy: From a Universal Strategy to That of the European Union}

A suitable starting point for discussion would appear to be the parameters established by the recently published Sustainable Development Goals included in the 2030 Agenda for Sustainable Development, passed by the UN General Assembly in September 2015. Although all 17 goals are interrelated, some of them are more closely linked than others, amongst them those that serve as a basis for this chapter. The goals in question are numbers $7,8,9,13$ and 14, namely those that state the need to ensure access to 'affordable, reliable, sustainable and modern energy for all'; promote 'sustained, inclusive and sustainable economic growth, full and productive employment and decent work for all'; build 'resilient infrastructure, promote inclusive and sustainable industrialization and foster innovation'; take 'urgent action to combat climate change and its impacts'; and, last but not least, 'conserve and sustainably use the oceans, seas and marine resources for sustainable development'.

This new framework in turn rests on the foundations provided by previous initiatives in the energy field promoted by the same platform, the United Nations, in recent years. Sustainable development is considered to be a pillar (although this situation, unfortunately, is still more theoretical than real), thus a significant proportion of the 'Sustainable Energy for All' initiative, launched by the UN Secretary-General in 2012 to mobilise action from all sectors of society in support of three interlinked objectives to be achieved by 2030: providing universal access to

\footnotetext{
${ }^{5}$ See Triantaphyllou (2009), pp. 225-241, particularly p. 229.

${ }^{6}$ High-level Black Sea Stakeholder Conference (2014), loc. cit. p. 4.

${ }^{7}$ UNGA Resolution 70/1, Transforming Our World: the 2030 Agenda for Sustainable Development, A/RES/70/1.
} 
modern energy services, doubling the global rate of improvement in energy efficiency and doubling the share of renewable energy in the global energy mix. Similarly, the objective of sustainable development is one of the main foundations of a number of significant Reports issued by the United Nations Secretary-General, of which we will mention some of the most relevant for our purposes. Thus, the principle of sustainable development to a greater or lesser extent permeates the structure of the following documents: the United Nations Secretary-General's Report on Marine Renewable Energies, $2012 ;^{8}$ the Climate Change Expert Group's Report on Renewable Energies, published some months previously; ${ }^{9}$ or the report on new and emerging technologies. ${ }^{10}$ Additionally, the United Nations General Assembly's open-ended informal consultative process on the Oceans and the Law of the Sea (UNICPOLOS), whose mandate is precisely to deal with matters relating to oceans within the context of sustainable development, devoted its 13th meeting, held in 2012, to discussing above all the subject of marine renewable energies, with a focus that can generally considered to be highly positive. ${ }^{11}$

Within the sphere of the European Union, it should be remembered that along with its exclusive competence on conservation on marine biological resources, ${ }^{12}$ the EU also has shared competences on other aspects under the common fisheries policy, energy, environment or transport, amongst other fields that can be relevant here. ${ }^{13}$ In addition to this, sustainable development is a general and transversal goal, ${ }^{14}$ and in line with this the Integrated Maritime Policy is one of the EU's vehicles for promoting the coherent adoption and coordination of decisions aimed at maximising sustainable development, economic growth and cohesion between Member States. Amongst the policies included under this umbrella are two with particular relevance for our case: blue growth and sea basin strategies, that for the Black Sea being included amongst the latter. In any event, it should also be borne in mind that the Black Sea basin is also a target for other EU policies and initiatives, which will be considered below; a case in point is the European Neighbourhood Policy (ENP), in which sustainable development is seen as a common value that partner States agree to accept. ${ }^{15}$

Remaining for the moment within the general sphere, it should be noted that blue growth has been an ever-present discourse within the European Union in recent years, but particularly since 2012, when the Commission drafted its

\footnotetext{
${ }^{8} \mathrm{UN}$ Doc. A/67/79.

${ }^{9}$ IPCC, Special Report on Renewable Energy Sources and Climate Change Mitigation (2011).

10 "New and emerging technologies: renewable energy for development", UN Doc. E/CN.16/2010/ 4.

${ }^{11}$ See http://www.un.org/Depts/los/consultative_process/consultative_process.htm.

${ }^{12}$ TFEU, Article 3.

${ }^{13} \mathrm{TFEU}$, Article 4.

${ }^{14} \mathrm{TEU}$, Article 3 and TFEU, Article 11.

${ }^{15}$ See Joint Consultation Paper. Towards a new European Neighbourhood Policy, JOIN (2015) 6 final, 4-3-2015, particularly pp. 1-3.
} 
Communication on Blue Growth: Opportunities for Marine and Maritime Sustainable Growth. In this document, together with other aspects of the blue economy, blue energy is seen as one of its priority areas for action and one that could aid job creation, basically in coastal regions. The Commission mentions EU industry's position as a world leader in the sector and highlights blue energy's capacity to contribute to 'reductions in carbon emissions outside Europe' through exports, the possibility of exploring 'synergies [...] with the offshore conventional energy sector' (e.g. with regard to infrastructure and safety challenges) and the potential to 'secure affordable energy supplies in the EU'. ${ }^{16}$

With this as a starting point, more recent documents have also acknowledged the important role that can be played by marine energy resources, for example the 2013 Communication on Energy Technologies and Innovation ${ }^{17}$ or the Communication on Blue Energy: Action Needed to Deliver on the Potential of Ocean Energy in European Seas and Oceans by 2020 and Beyond, adopted in 2014. The latter includes, in addition to an overview of the current situation and the main opportunities and threats remaining, an 'Action Plan for Ocean Energy', which envisages a two-step approach: a first phase (2014-2016) that includes the setting up of an Ocean Energy Forum to bring stakeholders together in order to develop a shared understanding of the main problems and devise workable solutions, as well as the development of an Ocean Energy Strategic Roadmap, and a second phase (2017-2020) that contemplates the possibility of developing a European Industrial Initiative based on the outcomes of the first stage. ${ }^{18}$ A few months later, in its Communication Innovation in the Blue Economy: Realising the Potential of Our Seas and Oceans for Jobs and Growth, also dated 2014, the Commission highlights, amongst other aspects, the need to increase knowledge of our seas in order to promote growth in the blue economy, thereby eliminating the hindrances caused by a current lack of information that is holding back innovation in this area; the setting up of a 'sustainable process', through a variety of channels, in order to 'ensure that marine data is easily accessible, interoperable and free of restrictions on use, with a specific target of developing a multi-resolution map of the entire seabed and overlying water column of European waters by 2020'; the creation of an information platform across the whole Horizon 2020 programme in which, in collaboration with Member States, it is intended to include information on nationally funded marine research projects; and the encouragement of 'stakeholders in the blue economy to apply for a Knowledge Alliance and marine Sector Skills Alliance'. ${ }^{19}$

\footnotetext{
${ }^{16} \mathrm{COM}$ (2012) 494 final, 13-9-2012, p. 8.

${ }^{17} \mathrm{COM}$ (2013) 253 final, 2-5-2013.

${ }^{18} \mathrm{COM}$ (2014) 8 final, 20-1-2014, particularly pp. 5-9.

${ }^{19} \mathrm{COM}$ (2014) 254 final, 8-5-2014.
} 


\section{Sources of Marine Renewable Energies and Adequacy in the Case of the Black Sea}

\subsection{Kinds of Marine Renewable Energies}

Marine renewable energies are a form of renewable energy deriving from the various natural processes that take place in the marine environment. There are four kinds of such energy, namely ocean energy, wind energy from turbines located in offshore areas, geothermal energy derived from submarine geothermal resources and bioenergy derived from marine biomass, particularly ocean-derived algae. In turn, renewable ocean energy comes from six distinct sources, each with different origins and requiring different technologies for conversion but having in common the fact that they are all obtained from the potential, kinetic, thermal and chemical energy of seawater. These six distinct sources are waves, tidal range, tidal currents, ocean currents, ocean thermal energy conversion and, finally, salinity gradients. More specifically, waves, which are generated by the action of wind on water, produce energy that can be harnessed. With regard to tides, their amplitude generates energy through the cyclical rise and fall in the height of the ocean. The same is true of tidal currents, which are generated by horizontal movements of water, their flows resulting from the rise and fall of the tide. Ocean currents, which exist in the open ocean, are another source of energy. Ocean thermal energy conversion, on the other hand, is a technology for taking advantage of the solar energy absorbed by the oceans, based on the temperature difference between the top layers of water and those at a greater depth, which are much colder. However, a minimum temperature difference of $20^{\circ} \mathrm{C}$ between layers is needed in order to harness this energy, which can therefore only be produced in certain parts of the world, such as equatorial and tropical regions. Finally, salinity gradients arise from the mixing of freshwater and seawater, which takes place at river mouths and releases energy as heat. This energy can be harnessed through a process of inverse electrodialysis, based on the difference in chemical potential between freshwater and seawater, or through an osmotic power process based on the natural tendency of the two types of water to mix together. $^{20}$

The development status of these technologies differs widely, although most of them are still either embryonic or in their infancy, ranging as they do from the conceptual stage to the prototype stage, taking in the pure research and development stage on their way. ${ }^{21}$ The IPCC highlights tidal range technology as being the most advanced and in fact as the only form of ocean energy technology (excluding marine wind energy technology) that can currently be considered 'mature'. 22

\footnotetext{
${ }^{20}$ IPCC, Special Report on Renewable Energy Sources and Climate Change Mitigation (2011)..., loc. cit., pp. $503 \mathrm{ff}$.

${ }^{21}$ Ibid., Chap. 6.3.1.

${ }^{22}$ Ibid.
} 
Although marine energy technologies are still generally at an early stage of development, it has to be said that they could make much swifter progress if investment in them were higher. Prominent amongst the leaders in the development and commercialisation of marine renewable energy technologies are nations such as the United Kingdom, Ireland, the United States, Australia, New Zealand, Finland, Denmark, Belgium, France, Germany and Japan. ${ }^{23}$ However, the economic crisis that has been affecting a number of the world's developed countries has had necessarily a negative effect on the flow of investment towards technologies of this kind.

Although forecasts vary widely, depending on who is making the prediction, a prudent approach indicates that any significant deployment of ocean energy technologies is unlikely to occur before 2030, whilst commercial deployments are expected to continue expanding beyond $2050 .{ }^{24}$ It remains to be seen, therefore, when these technologies will be able to make a significant contribution to the global energy supply. At the moment, only marine wind energy can be considered to be relatively close to beginning to be competitive with fossil fuels or nuclear energy. However, it must be said that in spite of the incipient status of all marine renewable energies, forecasts of their potential are on the whole clearly optimistic. According to the IPCC, the potential for technically exploitable marine renewable energies, marine wind power excluded, is estimated at some 7400 exajules (EJ) per year. ${ }^{25}$ This figure is considered to be more than enough to meet human energy needs not only at present but also well into the future. ${ }^{26}$

\subsection{Marine Renewable Energies and the Black Sea}

If we take the parameters of sustainable development, and by extension its three constituent dimensions, namely its economic, social and environmental aspects, it is clear that marine renewable energies score very highly in this regard, as the UN Secretary General's 2012 report demonstrates. ${ }^{27}$ A similar conclusion was also reached in the UNICPOLOS meeting devoted to marine renewable energies,${ }^{28}$ the

\footnotetext{
${ }^{23}$ Nevertheless, the list of leading countries in this sector varies according to the source consulted. For example, the countries mentioned in the Report of the UN Secretary-General on marine renewable energies, published in 2012, do not exactly coincide with those that appear in other places, such as specialist websites. See, in any case, the above-mentioned report, UN Doc. A/67/ 79, dated 4 April 2012, p. 8.

${ }^{24}$ IPCC, Special Report on Renewable Energy Sources and Climate Change Mitigation (2011)..., loc. cit., p. 527.

${ }^{25}$ Ibid., p. 501.

${ }^{26}$ Ibid. and UN Doc. A/67/79, pp. 6-7.

${ }^{27} \mathrm{UN}$ Doc. A/67/79, pp. 4 ff.

${ }^{28}$ See, for example, 25 Earth Negotiations Bulletin, Number 88 (2012), p. 5; and Report on the work of the United Nations Open-ended Informal Consultative Process on Oceans and the Law of the Sea at its thirteenth meeting, Doc. A/67/120 (2012).
} 
idea also being supported by doctrinal studies on the subject. ${ }^{29}$ Although it is true that certain problems or challenges can always be mentioned, particularly in the economic and environmental spheres, ${ }^{30}$ the overall balance is nevertheless clearly favourable since the benefits of sustainable development from all angles are selfevident (job creation, stimulus to the economy, improved access to energy, energy security, reduction of emissions, climate change mitigation, zero risk of hydrocarbon spills and a reduction in the probability of hazardous accidents, to name but a few).

Without prejudice to the above, however, it should be realised that it will never be possible to obtain all of the various kinds of renewable energy in all possible surroundings. We have seen how some kinds of marine energy are dependent on certain particular physical characteristics such as temperature or the existence of currents, amongst others. Taking this into account, the Black Sea has the potential for at least some forms of marine energy, namely marine wind energy, wave energy, tidal barrages and the production of biofuels. ${ }^{31}$ Furthermore, it should be noted that the current situation of environmental degradation affecting the Black Sea makes it an ideal space for investing in climate-friendly technologies since they help to reduce emissions and avoid the risk of accidents with serious consequences, unlike, for example, offshore oil rigs.

However, we should also be aware that many aspects of the harnessing and use of energy resources, marine energy included, often require transnational management and inter-State cooperation (e.g. basic issues such as cable laying, data exchange, network connections, etc.) that are not always easy to achieve in a space that has historically been marked not only by the absence of mutual trust but also by rivalries between neighbouring states and even open conflict.

\footnotetext{
${ }^{29}$ Abad Castelos (2014), pp. 221-237; particularly pp. 223-225.

${ }^{30}$ It must be acknowledged that issues can also rise in the social sphere, for example a rejection of the more visible kinds of technology in certain surroundings; see Kerr et al. (2015), pp. 108-115. Above all, however, the main challenges are to be found in the economic sphere, due to the huge costs involved and the massive investments needed, and in the environmental sphere, resulting from other possible negative impacts; see Wright (2014), pp. 23-30. Nevertheless, further research is needed to determine the scope of certain potential problems (e.g. the impact of certain devices on marine fauna and the possible adverse impact of tidal barrages). A more detailed overview is provided in Copping, Battey et al. (2014), pp. 1-11.

${ }^{31}$ Study to Support the Development of Sea Basin Cooperation in the Mediterranean, Adriatic and Ionian, and Black Sea, Task 4 Report, Black Sea-Identification of Elements for Sea Basin Cooperation (2014), MARE/2012/07-Ref. No 2, pp. 3 ff. also see United States Agency for International Development, Black Sea Regional Transmission Planning Project: Renewable Energy Compendium Report, Washington, 2012, pp. 17 ff.
} 


\section{The European Union and Blue Energy in the Black Sea}

It is essential to bear in mind that the EU's Integrated Maritime Policy (IMP), which first came into being in 2007, in 2009 acquired an international dimension transcending its borders before adopting, in 2012, blue growth as one of its main pillars, at least from the theoretical standpoint. In this sphere, the EU has carried out a strategic assessment of the potential for cooperation in the context of Blue Growth in the various sea basins concerned and has sponsored a series of studies, through DG MARE, to analyse its blue growth potential, examining in detail each of the different development models of its maritime industries, with the aim of drafting specific plans for the future. In this context, the Black Sea has also come under the spotlight in order to explore its current situation and the potential added value that maritime cooperation could bring to the surrounding area, identifying the main maritime players in the region and the aspects that would benefit from a sea-basin approach. This has taken the form of a report, published in 2014 and titled Black Sea-Identification of Elements for Sea Basin Cooperation, which lists the most significant initiatives and programmes in the area of maritime cooperation at sea basin level, maps the existing projects and initiatives with a maritime dimension and enumerates the possible sources of funding for blue growth projects in the Black Sea. ${ }^{32}$ The report also identifies what are considered to be the priorities, ${ }^{33}$ which in the case of sectoral categories include offshore renewable energies, together with offshore oil and gas, as a means of ensuring energy security in the region. ${ }^{34}$ Horizontal actions cover four main areas, each with its corresponding sub-categories, namely 'Planning a blue economy' (Maritime Spatial Planning; development of smart infrastructure, etc.), developing knowledge (joint data collection; capacity-building across individuals, institutions and society; sharing maritime culture and heritage), supporting business growth (facilitating access to finance; promoting innovation; development of maritime clusters), and enhancing the environment (preserving, protecting and improving the quality of the coastal and marine environment and heritage; ecosystem monitoring; building resilience to the impacts of climate change). ${ }^{35}$

\footnotetext{
${ }^{32}$ Black Sea-Identification of Elements for Sea Basin Cooperation (2014)... loc. cit., introduction.

${ }^{33}$ Nevertheless, it should be pointed out that the starting point for the study is the acknowledged fact that cooperation between the EU and other Black Sea riparian countries have to date taken place largely on a bilateral basis, which is in contrast to EU initiatives in other geographic regions such as the Baltic, where actions were conceived from the beginning in a regional format and have therefore benefited from a significant institutional presence; cf. ibid., p. 8; also see ibid., p. 30.

The fact that EU cooperation with Black Sea regions countries is basically bilateral has in turn meant that multilateral initiatives have largely been sectoral, such as those which will be referred to below (INOGATE, TRACECA and PETrA).

${ }^{34}$ Black Sea-Identification of Elements for Sea Basin Cooperation (2014)... loc. cit., introduction.

${ }^{35}$ Ibid.
} 
Within the same framework, two high-level Black Sea Stakeholder Conferences have been organised, the first in Bucharest (2014) and the second in Sofia (2015). ${ }^{36}$ The EU's expressly declared aim in this regard is to promote dialogue between all stakeholders, both public and private, to build their capacity and to support cooperative actions.

Mention should also be made of the publication of another EU study in November 2015, Project in Support to the Development of Blue Economy and Integrated Maritime Policy in the Black Sea. Concept Paper. ${ }^{37}$ This project concept is currently under discussion with the coastal countries and regional organisations. ${ }^{38}$ It is, however, worth noting that its priorities do not include energy issues, the leitmotiv of the report being that the development of maritime and coastal tourism should be the central theme.

Furthermore, in 2007 the EU adopted a specific regional initiative, its Black Sea Synergy, which lays no claim to being a new policy, but rather a complementary initiative aimed at reinforcing existing ones, since the EU has either adopted or is a partner in various programmes affecting the Black Sea through a number of channels, and thus funded from a variety of sources (and, therefore, with a different status with regard to the various States, depending on their situation). Thus, before looking at Black Sea Synergy, it must be noted that the EU's institutions have adopted significant measures regarding the Black Sea in the framework of Turkey's pre-accession process, the ENP ${ }^{39}$ and the Strategic Partnership with Russia. Similarly, Horizon 2020, the EU Framework Programme for Research and Innovation for 2014-2020, also contains a specific call for the Black Sea region. Although Black Sea Horizon does not specifically include energy issues amongst its explicit aims, any renewal energy project would fit perfectly with them, especially given the fact that its seventh and final stated sub-objectives is precisely to identify

\footnotetext{
${ }^{36}$ For documents and minutes of discussions see: "Sustainable development of the blue economy of the Black Sea", Enhancing marine and maritime cooperation, Bucharest, Romania, 30 January 2014 (Summary of Presentations and Discussions); and 2nd Black Sea Stakeholders Conference Sofia, 24th March 2015 Background paper (see http://ec.europa.eu/maritimeaffairs/events/2015/ 03/events_20150324_01_en.htm).

${ }^{37}$ Project in support to the development of Blue Economy and Integrated Maritime Policy in the Black Sea (2015), Concept paper, EU, 20 November 2015.

${ }^{38}$ See http://ec.europa.eu/maritimeaffairs/policy/sea_basins/black_sea/index_en.htm.

The European Commission also supports the effort of a number of research institutes and public stakeholders from all Black Sea countries to compile all relevant data and create a digital map of the Black Sea seabed, including geology, habitats and marine life. A first version of the map is expected to be ready in 2016; ibid.

${ }^{39}$ The ENI Cross-Border Cooperation Programme (CBC) (2014-2020), successor to the Joint Operational Programme (2007-2013), lies within the framework of the ENP and is thus financed through its funding instrument, although it should be borne in mind that most of the projects currently envisaged within its framework have no direct connection with the maritime sphere, being related instead with stimulating entrepreneurship and other aspects, etc. See European External Action Service and European Commission-DG for Development and CooperationEuropeAid, Programming of the European Neighbourhood Instrument (ENI) 2014-2020; Programming document for EU support to ENI Cross-Border Cooperation (2014-2020).
} 
challenging thematic areas for mutual science, technology and innovation cooperation' ${ }^{40}$ And, finally, various initiatives affecting the Black Sea have been carried out through other cooperative programmes in the energy sphere in which the EU is a partner, such as INOGATE, ${ }^{41}$ TRACECA $^{42}$ and PETrA, ${ }^{43}$ although to date no significant initiatives having to do with blue energy appear to have arisen within them.

Black Sea Synergy, as we have already seen, is a regional initiative that came into being in 2007 with very broad goals that went far beyond maritime, energy, transport or environmental aspects, its cornerstone being the Commission's communication Black Sea Synergy-A New Regional Cooperation Initiative. The 'primary task' of this initiative would be 'the development of cooperation within the Black Sea region and also between the region as a whole and the European Union', based on the common interests of the EU and the Black Sea region. The scope of its actions could extend beyond the region itself since many activities are linked to neighbouring regions such as the Caspian Sea, Central Asia and South-Eastern Europe and such cooperation would therefore include 'substantial interregional elements'. ${ }^{44}$ The Synergy refers to a wide range of cooperation areas, which in turn include other matters such as democracy, respect for human rights and good governance; managing movement and improving security; 'frozen' conflicts; fisheries; trade; research and education networks; science and technology; employment and social affairs; and regional development, amongst others. ${ }^{45}$

As far as energy is concerned, although from the very beginning reference was made to the need to 'develop a clearer focus on alternative energy sources', ${ }^{46}$ the approach comes from the underlying perspective of the region's strategic importance for EU energy security, in part because it is an energy-producing region but mainly because it is a transport corridor for conventional hydrocarbons. The

\footnotetext{
${ }^{40}$ See http://ec.europa.eu/maritimeaffairs/policy/sea_basins/black_sea/black-sea-horizon_en.htm.

${ }^{41}$ INOGATE is a regional energy cooperation programme between the European Union, Turkey and various States from the former Soviet Union (Armenia, Azerbaijan, Belarus, Georgia, Kazakhstan, Kyrgyzstan, Moldova, Turkmenistan, Ukraine, Uzbekistan and Tajikistan) that began in 1995 (Russia is not a member, although it enjoys observer status). Although its original focus was the oil and gas pipelines running from the Caucasus to the European Union, in 2004, as a result of the Baku Initiative, it widened its goals. This initiative was the outcome of the dialogue on energy cooperation between the EU and INOGATE member countries with a view to incorporating the following areas: enhancing energy security; harmonising legal and institutional frameworks in order to liberalise the energy market between partner countries; developing sustainable energy; and attracting investment towards energy projects of common and regional interest; see http://www.inogate.org/.

${ }^{42}$ This is another international cooperation programme in the field of energy transport: the Transport Corridor Europe-Caucasus-Asia, in which the partners are the EU and 14 states from the Eastern Europe, Caucasus and Central Asia region; see http://www.traceca-org.org/en/home.

${ }^{43}$ Black Sea Pan-European Transport Area.

${ }^{44}$ COM (2007) 160 final, 11-4-2007, p. 3.

${ }^{45}$ Ibid., pp. $3 \mathrm{ff}$.

${ }^{46}$ As well as energy efficiency and energy saving; ibid., p. 5.
} 
Commission's proposal thus contemplates, on the one hand, ongoing improvement of the EU's relations with energy producer, transit and consumer countries, within the framework of a dialogue on energy security (with a view to promoting legal and regulatory harmonisation through the Baku Initiative ${ }^{47}$ ) and, on the other, to increase energy stability by constructing new energy infrastructure and upgrading the existing one. ${ }^{48}$ The following year (2008), the European Parliament highlighted the importance of strengthening cooperation between the EU and countries in the region, ${ }^{49}$ whilst the Commission proposed, in its Report on the First Year of Implementation of Black Sea Synergy, the establishing of 'sectoral partnerships' in the fields of 'transport, environment [and] energy'. ${ }^{50}$ In the same vein, the European Parliament made a second appeal to develop EU policies towards the region in a subsequent resolution (2011).

In 2015, the Commission and the High Representative of the European Union for Foreign Affairs and Security Policy adopted a Joint Staff Working Document titled Black Sea Synergy: Review of a Regional Cooperation Initiative, covering the years 2009-2014. ${ }^{51}$ The document provides a review of the initiative and highlights a number of 'lessons learnt' intended to inform the future development of the Synergy, given that the events in Ukraine after the illegal annexation of the Crimean peninsula by the Russian Federation had a significant impact, leading to the suspension of all EU-funded projects in the affected area (with the exception of those in support of civil society) and a reassessment of relations with Russia. ${ }^{52}$

However, the 2015 Report on the review of Black Sea Synergy makes no mention whatsoever of any progress regarding renewable energies in general, not to mention marine ones. Reference is made to EU support for certain projects concerning specific hydrocarbon deposits, pipelines and means of transport, as well as to Moldova and Ukraine becoming members of the Energy Community and to the roadmap on energy cooperation with Russia until $2050,{ }^{53}$ which is currently suspended as a result of recent events and will anyway need reviewing in the future. In this regard, it should be pointed out that the weakness of political determination amongst the region's countries, when taken in combination with recent conflicts, significantly increases the complexity of this scenario. ${ }^{54}$

\footnotetext{
${ }^{47}$ Referred to above, in the footnote on INOGATE.

${ }^{48}$ COM (2007) 160 final. .., loc. cit., p. 5.

${ }^{49}$ Resolution of 17-6-2008.

${ }^{50}$ COM (2008) 391 final, 19-6-2008.

${ }^{51}$ SWD (2015) 6 final, 20-1-2015.

${ }^{52}$ Renewal of cooperation depends on fulfilment of the 2014 and 2015 Minsk Agreements by Russia; see European Parliament, Report on the strategic military situation in the Black Sea Basin following the illegal annexation of Crimea by Russia, A8-0171/2015, 21-5-2015; p. 8.

${ }^{53}$ Roadmap EU-Russia Energy Cooperation until 2050 (2013); see pp. $21 \mathrm{ff}$. on the subject of renewable energies in general.

${ }^{54}$ Report on the strategic military situation in the Black Sea Basin following the illegal annexation of Crimea by Russia ... loc. cit., pp. 1, 4-5 and 11.
} 


\section{The Main Challenges in the Black Sea Basin that the European Union Can Help to Overcome}

The Black Sea needs a regional approach because the challenges it faces, one of them energy, are on the same scale. And energy, in turn, is linked to other aspects that can only be tackled properly from an international perspective and on a regional basis, such as transport and protection of the environment.

This is not the place to examine all the various challenges that the EU can help to overcome since it would go far beyond the scope of the present work, which will only look at some of them, whilst acknowledging that the matter is indeed an extremely complex one. It is important to remember that in addition to the many challenges posed by marine renewable energies themselves (technology costs; transport infrastructure network costs, suitable port installations and specialised vessels; authorisation and licensing procedures; lack of subsidies; possible objections by the general public; technical problems such as connecting to the grid; etc.), there are two other problem areas that have to be considered. Firstly, the Black Sea basin is a particularly complex physical and geographic area in which a variety of different policies come into play, for example the EU's Integrated Maritime Policy, which involves international elements, development cooperation policy, the ENP, Turkey's pre-accession process and certain complementary regional strategies, some of which contain interregional elements. Furthermore, all the above elements come together in a region that includes countries that are EU Member States and others that are not. Secondly, and as if the above were not enough, from a geopolitical standpoint the area is home to a number of major conflicts, some of them 'frozen' and others that have only recently arisen. The area is one in which simply attempting to establish cooperation between certain countries in any field whatsoever is a veritable challenge. Without prejudice to the foregoing, it is necessary here to point out a further set of issues that come into play.

The first point to note is that the Black Sea Synergy contains an excessive number of spheres of action: it tries to approach too many issues but, by neglecting to establish priority goals, focuses on none in particular, which amongst other implications could dilute its power. ${ }^{55}$ Furthermore, the EU could also make more use of the Black Sea Economic Cooperation (BSEC), an organisation created in 1992 for the purpose of promoting cooperation in the regions and that could help to enhance its effectiveness to plan useful projects, ${ }^{56}$ particularly when we consider that one of its spheres of cooperation is precisely that of energy. Another interesting factor in this regard is that Russia (in common with other member countries) has

\footnotetext{
${ }^{55} \mathrm{~A}$ critique of the confusion created by the excessive number of possible areas of cooperation combined with the lack of any hierarchy between them can also be found in Devrim and Grau (2010), pp. 244-251; p. 248.

${ }^{56}$ Its Member States are Albania, Armenia, Azerbaijan, Bulgaria, Georgia, Greece, Moldova, Romania, Russia, Serbia, Turkey and Ukraine; see http://www.bsec-organization.org/Pages/ homepage.aspx.
} 
always sought to maintain the organisation's openly non-political nature, rejecting any attempt to include other issues that might refer to territorial disputes or security matters. ${ }^{57}$

Second, there is room for improving the consistency of the EU's actions. If blue energy is a key aspect of blue growth, which is in turn a key aspect of the EU's Integrated Maritime Policy, why is it not given the same importance across all the EU's policies and strategies? Thus, for example, in the Energy Union Package contained in the Commission's 2015 Communication concerning a Framework Strategy for a Resilient Energy Union with a Forward-Looking Climate Change Policy, there is no specific section devoted to blue energy: in fact, it does not even deserve a mention, ${ }^{58}$ the principal focus being the diversification of supply as far as suppliers and transport routes are concerned in order to guarantee energy security. The most innovative vision of the future to appear in the document would appear to relate more to exploring the full potential of liquefied natural gas (LNG) rather than to renewable energies. ${ }^{59}$ In a similar vein, the 2015 concept paper Project in Support to the Development of Blue Economy and Integrated Maritime Policy in the Black Sea, referred to earlier, in reality revolves around promoting tourism. ${ }^{60}$ Much the same can be said of the most recent revision of the Black Sea Synergy, carried out in 2015 through the afore-mentioned Joint Staff Working Document, which also makes no mention whatsoever of blue energy and deals only with hydrocarbon deposits or recent and future gas pipeline projects. ${ }^{61}$ In light of all the above, the EU could do worse in the future than to turn the spotlight on renewable energies in the various sea basins, of which the Black Sea is one, and thus by extension on blue energy, in order to improve consistency between all its different actions and instruments.

Another challenge that the EU can undoubtedly do much to help overcome is that of spatial planning, in order to plan when and where human activities take place at sea. Maritime spatial planning reduces conflicts, encourages investment, increases coordination not only between administrations in each country but also between countries and protects the environment by helping with the early identification of impact and opportunities for multiple use of space. ${ }^{62}$ After the adoption of the Directive on maritime spatial planning, Member States are obliged to establish

\footnotetext{
${ }^{57}$ See the press release on the declarations made by the Minister for Foreign Affairs in this regard; "Rusia apuesta por mantener el carácter apolítico de la Organización para la Cooperación Económica del Mar Negro (BSEC)", Sputnik Mundo, 10-12-2015 (http://mundo.sputniknews. com/economia/20151210/1054682272/rusia-bsec-apolitico.html).

${ }^{58} \mathrm{COM}$ (2015) 80 final, 25-2-2015.

${ }^{59}$ Ibid., pp. 4 ff.

${ }^{60}$ Project in support to the development of Blue Economy and Integrated Maritime Policy in the Black Sea. Concept paper (2015)..., loc. cit.

${ }^{61} \mathrm{SWD}$ (2015). . . loc. cit.., pp. $4 \mathrm{ff}$.

${ }^{62} \mathrm{Cf}$. the European Commission's webpage on maritime spatial planning: http://ec.europa.eu/ maritimeaffairs/policy/maritime_spatial_planning/index_en.htm (last accessed 20-2-2016).
} 
and implement a procedure for planning activities and uses in their marine waters ${ }^{63}$, in which it therefore also becomes necessary to include all possible blue energy projects. ${ }^{64}$ However, there is a lack of maritime spatial planning (MSP) in the Black Sea basin as a whole and in the maritime areas adjoining the majority of its riparian states, as highlighted in the 2014 report produced on behalf of the Commission, Black Sea-Identification of Elements for Sea Basin Cooperation. ${ }^{65}$ It would therefore seem essential for the EU to also promote the adoption of national maritime spatial plans in other Black Sea riparian countries. ${ }^{66}$

The third and final challenge is that of public-private partnerships, which are encouraged in a number of documents relevant to the topic of this chapter, such as the Commission's 2014 Communication on Blue Energy, ${ }^{67}$ the Black Sea Synergy, the Horizon 2020 programme $^{68}$ or the 2014 report produced on behalf of the Commission, Black Sea-Identification of Elements for Sea Basin Cooperation. The premise is obviously that companies are a vital element of society, and their contribution to it is indispensable. And this is indeed the case: private sector intervention should clearly represent an obvious advantage, ${ }^{69}$ a condition that in this case is fulfilled $a b$ initio since the role that plays in matters of energy exploration and exploitation is an irreplaceable one. Nevertheless, there is still a dual challenge to be faced. The first of these is that it is hard to forge certain links. The Black Sea-Identification of Elements for Sea Basin Cooperation report highlights this issue when it says that even 'where co-operative platforms exist for the sea basin's key MEAs, they often do not bring together all relevant parties (public, private, academic partners) ${ }^{, 70}$. Second, the fact that such initiatives could involve

\footnotetext{
${ }^{63}$ Directive 2014/89/EU of the European Parliament and of the Council, 23-8-2014, establishing a framework for maritime spatial planning; OJEU L 257/135, 28-8-2014.

${ }^{64}$ See O'Hagan (2012) and Soininen (2012), pp. 85-118.

${ }^{65}$ Black Sea-Identification of Elements for Sea Basin Cooperation (2014) ... loc. cit., introduction.

${ }^{66}$ On their importance in relation to marine renewable energies, see Wright et al. (2016), pp. 126-134; pp. 131 and 132.

${ }^{67} \mathrm{COM}$ (2014) 8 final, 20-1-2014, pp. 10 ff. See also: Commission Staff Working Document, Impact Assessment (Accompanying the document Communication from the Commission to the European Parliament, the Council, the European Economic and Social Committee and the Committee of the Regions), Ocean Energy: Action needed to deliver on the potential of ocean energy by 2020 and beyond, SWD (2014) 13 final, Brussels, 20-1-2014; pp. 22 ff.

${ }^{68}$ See SWD (2015)... loc. cit., pp. 9 and 10.

${ }^{69}$ This is reflected in the views of experts in the subject, as well as in national plans and regulations, particularly from the development cooperation standpoint, taking into consideration, amongst other requirements, that of compatibility between objectives (e.g. in social, environmental and sustainable development terms), complementarity, the significant nature of the private company's contribution in terms of human and material resources, etc.; see, amongst others, Caplan (2006), pp. 11-14; Dizon-Reyes (2012-2013), pp. 799-819; Vinnyk (2013), pp. 17-36; Tiganescu (2013), pp. 519-526.

${ }^{70}$ Black Sea-Identification of Elements for Sea Basin Cooperation (2014) ... loc. cit., introduction.
} 
States with differing degrees of implementation of reforms in areas such as good governance and the fight against corruption implies an additional challenge in that the utmost precautions must be taken in order to ensure that public-private partnerships are structured in the best way possible. In this regard, a key point that should always be kept in mind is that the first priority in energy exploitation is that it should be done in the general interest, including all citizens, and not only in that of the companies concerned.

\section{Conclusion}

Marine renewable energies, like all renewable energies in general, appear to be the ideal solution from a sustainable development perspective. The range of difficulties that blue energy can help to surmount is enormous. Indeed, as the twenty-first century progresses, there is growing awareness that the energy potential of the seas and oceans may be so vast that it surpasses our current understanding.

The conflicts in the Black Sea basin, whether recent or 'frozen', condition a geopolitical scenario in which it is particularly difficult to construct any kind of regional cooperation. Some form of international collaboration, at least sub-regional in scope, will be a necessary precondition for establishing certain projects in the field of marine renewable energies in the area, as well as others relating to them. There is no magic formula for achieving such cooperation, but at the very least the EU should identify all the aspects in which it can help to pave the way. Similarly, it should also strive to achieve maximum coherence between its strategies, thereby maximising their effectiveness. Blue growth and blue energy should play a greater role in the European Union's projections and initiatives for all the sea basins within its scope, particularly that of the Black Sea.

\section{References}

Abad Castelos M (2014) Marine renewable energies: opportunities, law, and management. Ocean Dev Int Law 45:221-237

Adams R (1998) The ecological decline of the black sea. Colo J Int Environ Law Policy 9:209-217

Battey H, Brown-Saracino J, Massaua M, Smith C (2014) An international assessment of the environmental effects of marine energy development. Ocean Coast Manag 99:1-11

Caplan K (2006) Creating space for innovation: understanding enablers for multi-sector partnerships. Partnership matters. Curr Issues Cross Sect Collab 4:11-14

Devrim D, Grau M (2010) El (in)hospitalario mar Negro: la imaginación occidental y la estrategia multilateral en una región en disputa. Quaderns de la Mediterrània 13:244-251

Dizon-Reyes MGN (2012-13) Public-private partnership towards growth \& development: is it working? Philipp Law J 87:799-819

Kerr S, Colton J, Wright G (2015) Rights and ownership in sea country: implications of marine renewable energy for indigenous and local communities. Mar Policy 52:108-115 
O'Hagan AM (2012) Marine Spatial Planning (MSP) in the European Union and its application to marine renewable energy (WWW Document). Int Energy Agency Ocean Energy Syst. https:// www.ocean-energy-systems.org/library/in-depth-articles/document/marine-spatial-planningin-the-eu-and-its-application-to-marine-renewable-energy/

Oral N (2013) PSSA for the Black Sea. Univ Hawai'i Law Rev 35:787-804

Postiglione A (2007) The Mediterranean and black sea ecosystem under discussion. Env Policy Law 37:489-500

Soininen N (2012) Planning the marine area spatially - a reconciliation of competing interests? Int Law Mak Dipl Rev 12:85-118

Tiganescu AM (2013) Legal aspects of the contract of public-private partnership. Contemp Read Law Soc Just 5:519-526

Triantaphyllou D (2009) The 'security paradoxes' of the Black Sea region. Southeast Eur Black Sea Stud 9:225-241

Vinnyk OM (2013) The public-private partnership agreements: problems of legal regulation. Law Innov Soc 1:17-36

Wright G (2014) Strengthening the role of science in marine governance through environmental impact assessment: a case study of the marine renewable energy industry. Ocean Coast Manag 99:23-30

Wright $G$ et al (2016) Establishing a legal research agenda for ocean energy. Mar Policy 63:126-134

Open Access This chapter is licensed under the terms of the Creative Commons AttributionNonCommercial 4.0 International License (http://creativecommons.org/licenses/by-nc/4.0/), which permits any noncommercial use, sharing, adaptation, distribution and reproduction in any medium or format, as long as you give appropriate credit to the original author(s) and the source, provide a link to the Creative Commons license and indicate if changes were made.

The images or other third party material in this chapter are included in the chapter's Creative Commons license, unless indicated otherwise in a credit line to the material. If material is not included in the chapter's Creative Commons license and your intended use is not permitted by statutory regulation or exceeds the permitted use, you will need to obtain permission directly from the copyright holder. 